\title{
Hemolytic anemia in a 26-year-old woman with vomiting and fatigue
}

\author{
Malik Elharram MD, Vladimir Sapon-Cousineau MD, Vicky Tagalakis MD MSc
}

Cite as: CMAJ 2018 August 27;190:E1013-7. doi: 10.1503/cmaj.171147

$\mathbf{A}$

26-year-old black woman underwent evaluation in the emergency department after two weeks of worsening nausea, vomiting and fatigue. Her medical history included having had malaria at eight years of age, for which she had received treatment in Eritrea. A complete review of systems was unremarkable aside from a two-day history of a mild bitemporal headache. The patient stated no recent changes in her dietary habits or bowel movements. She did not take any medication or over-the-counter products, and she had never used illicit drugs. She had no history of venous thromboembolism.

Our patient's vital signs were as follows: temperature $36.7^{\circ} \mathrm{C}$, heart rate 87 beats/min, blood pressure 105/71 mm Hg, respiratory rate 16 breaths/min and oxygen saturation $100 \%$ on room air. She appeared fatigued and showed signs of pallor on her palms and nail beds. A complete neurologic examination that included cranial nerves, gait, reflexes, proprioception and sensation was unremarkable. The rest of the physical examination results were normal, including the absence of hepatosplenomegaly.

Laboratory investigations in the emergency department showed normocytic anemia (mean corpuscular volume [MCV] 89.9 [normal 80-96] fL), with hemoglobin 57 [normal 120-152] g/L, mild thrombocytopenia (platelets 119 [normal 150-400] $\times 10^{9} / \mathrm{L}$ ) and normal leukocyte count and differential. A preliminary workup for anemia showed elevated lactate dehydrogenase (> 1800 [normal 110-220] U/L) and mildly elevated total bilirubin (23 [normal 3-17] $\mu \mathrm{mol} / \mathrm{L}$ ), with a conjugated bilirubin of 6 (normal 0-5) $\mu \mathrm{mol} / \mathrm{L}$. The reticulocyte count was normal (26 [normal 7-31] $\left.\times 10^{3} / \mathrm{L}\right)$. These results, taken in totality, were consistent with hemolytic anemia. There were no previous laboratory results for comparison.

\section{What further evaluation should this patient undergo?}
a. Fibrinogen level
b. Coomb test
c. Peripheral blood smear
d. Malaria antigen test
e. All of the above

The answer is (e). All of the above are appropriate diagnostic tests for further workup of a hemolytic anemia for this patient. We excluded disseminated intravascular coagulation on the basis of a normal fibrinogen level and normal coagulation studies. To evaluate for autoimmune hemolytic anemia, we ordered a direct Coomb test, which was negative. This result, combined with a normal total complement test, allowed us to conclude that a diagnosis of autoimmune hemolytic anemia was unlikely. Direct Coomb tests have a sensitivity of $90 \%-95 \%$ and specificity of $99 \%$ in diagnosing autoimmune hemolytic anemia. ${ }^{1}$ We chose to order a rapid malaria antigen test even in the absence of recent travel, given our patient's medical history. The test was negative. To assess for underlying microangiopathic hemolytic anemia, we requested a peripheral blood smear, which showed polychromatophilia, macro-ovalocytes, hypersegmented neutrophils and large platelets (Figures 1 and 2). In addition, schistocytes and fragmented cells were present (Figure 2).

\section{Given the results of the peripheral blood smear, which of the following diagnoses should be considered?}
a. Microangiopathic anemia
b. Sickle cell crisis
c. Thalassemia
d. Paroxysmal nocturnal hemoglobinuria
e. Cobalamin deficiency

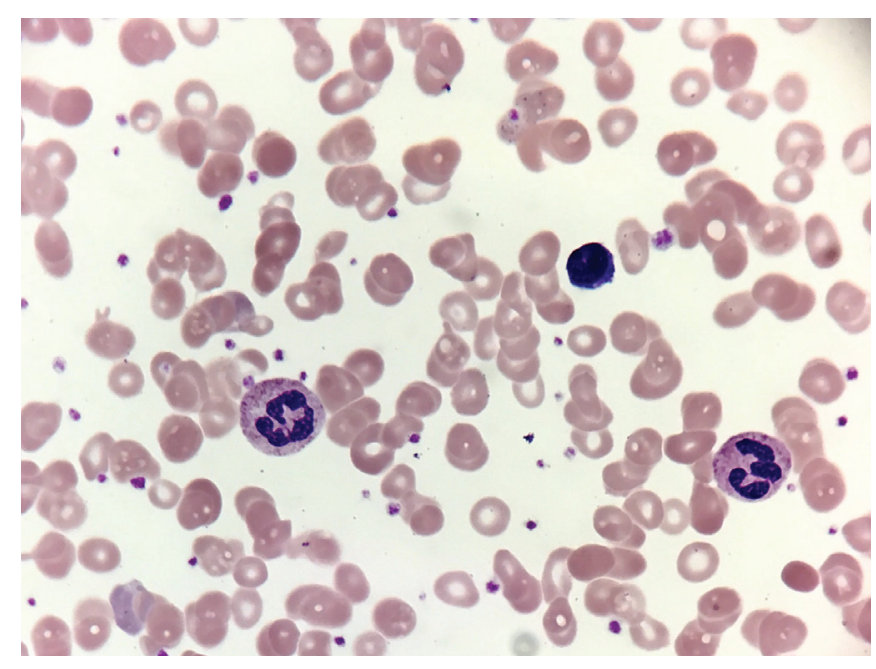

Figure 1: Peripheral blood smear from a 26-year-old black woman showing anisocytosis, poikilocytosis, macro-ovalocytes, hypersegmented neutrophils and large platelets. 


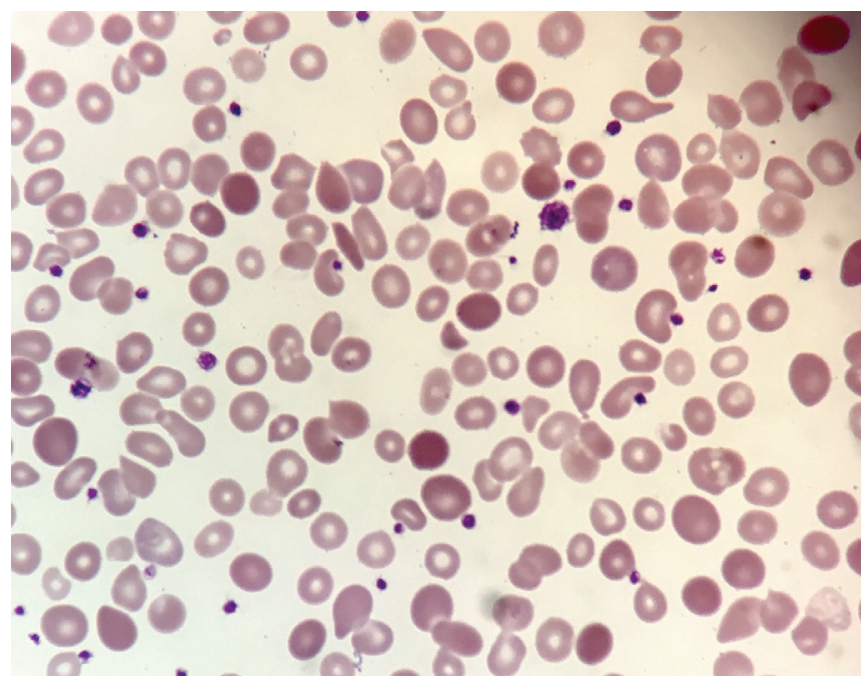

Figure 2: Peripheral blood smear from the same patient showing macroovalocytes and fragmented cells.

The answer is both (a) and (e). Both microangiopathic anemia and cobalamin (vitamin $B_{12}$ ) deficiency should be considered. Although our patient was originally from Sub-Saharan Africa, she had no history of sickle cell crisis and, with an absence of sickled red blood cells on peripheral smear, this diagnosis remained low on our differential. Paroxysmal nocturnal hemoglobinuria was possible given the presence of hemolysis with iron deficiency; however, it was unlikely, given our patient's negative history for venous and arterial thromboembolism, and the absence of leukopenia. Thalassemia could present with hemolytic anemia; however, our patient's peripheral smear showed macrocytosis as opposed to microcytic hypochromic anemia, which is classically seen in thalassemia.

The presence of schistocytes and fragmented cells supported a diagnosis of microangiopathic hemolytic anemia. At this point, our differential diagnosis included thrombotic thrombocytopenic purpura/hemolytic uremic syndrome (HUS) given the presence of thrombocytopenia and the findings consistent with microangiopathic hemolytic anemia on the peripheral blood smear. Thrombotic thrombocytopenic purpura was lower on our differential given the absence of other associated features, such as altered mental status, renal failure and fever. However, our patient presented with a bitemporal headache and mild thrombocytopenia, which cautioned us to keep this life-threatening diagnosis in mind. Regarding HUS, the patient did not have any history of food-borne illness, exposure to a contaminated water supply or any preceding episode of diarrhea. Furthermore, she had relatively mild thrombocytopenia without the evidence of acute kidney injury commonly associated with HUS. Box 1 summarizes the differential diagnosis of thrombotic microangiopathy. ${ }^{2}$

We considered vitamin $\mathrm{B}_{12}$ deficiency in our differential diagnosis given the presence of megaloblastic changes on the peripheral blood smear, including macro-ovalocytes, giant platelets and hypersegmented neutrophils. Furthermore, the inappropriately normal reticulocyte count in the context of

Box 1: Differential diagnosis of primary thrombotic microangiopathy ${ }^{2}$

Diagnosis Cause Clinical presentation

\section{Acquired disorders}

Thrombotic thrombocytopenic purpura

Hemolytic uremic syndrome (Shiga toxin-mediated)

Complement-mediated

Drug-mediated

(immune reaction)

Drug-mediated

(non-immune reaction)

\section{Hereditary disorders}

Thrombotic thrombocytopenic purpura

Complement-mediated

Metabolism-mediated

Coagulation-mediated
Autoantibody inhibition of ADAMTS13 activity

Enteric infection with Shiga toxin-secreting strain of Escherichia coli or Shigella dysenteriae

Autoantibody inhibition of complement factor $\mathrm{H}$ activity

Quinine and possibly other drugs with formation of drug-dependent antibodies

Multiple mechanisms

ADAMTS13 deficiency (homozygous or compound heterozygous for ADAMST13 mutations)

Mutations in complement genes causing uncontrolled activation of alternative complement pathway

Homozygous mutations in MMACHC

Homozygous mutations in DGKE
Diverse, including weakness, gastrointestinal symptoms, purpura and neurologic symptoms; acute kidney injury is uncommon

More common in children; presents with acute kidney injury after an episode of diarrhea

Acute kidney injury

Sudden onset of severe systemic symptoms and anuric renal failure

Gradual onset of renal failure over weeks or months

Usually presents in children (also possible in adults); acute kidney injury is uncommon

Usually presents in children (also possible in adults); acute kidney injury is common

Usually presents in children younger than 1 year; 1 case reported in an adult with hypertension and acute kidney injury

Usually presents in children younger than 1 year with acute kidney injury

*Adapted from George JN, Nester CM. Syndromes of thrombotic microangiopathy. N Engl J Med 2014;371:654-66 
severe anemia pointed to underlying bone marrow failure. Vitamin $B_{12}$ deficiency was subsequently confirmed with a serum level of 62 (normal 140-700) pmol/L. In addition, the patient was found to have concomitant iron deficiency, with a ferritin level of 38 (normal 50-300) $\mu \mathrm{g} / \mathrm{L}$, which could have been the reason for our patient's normal MCV.

Given the finding of severe vitamin $\mathrm{B}_{12}$ deficiency, we gave our patient vitamin $B_{12}$ parenterally and folic acid supplementation.

Box 2 (part 1 of 2): Case series and reports of vitamin $B_{12}$ deficiency and hemolysis

\begin{tabular}{|c|c|c|c|c|c|c|}
\hline Study & $\begin{array}{c}\text { No. of } \\
\text { patients }\end{array}$ & $\begin{array}{c}\text { Mean or median } \\
\text { age, } y r\end{array}$ & $\begin{array}{l}\text { Mean cobalamin } \\
\text { level, } \mathrm{pg} / \mathrm{mL}^{\star}\end{array}$ & $\begin{array}{c}\text { Other laboratory } \\
\text { values }\end{array}$ & Peripheral smear & $\begin{array}{c}\text { Clinical } \\
\text { presentation }\end{array}$ \\
\hline Acharya et al. ${ }^{4}$ & 3 & $\begin{array}{l}\text { Patient 1: } 55 \\
\text { Patient 2: } 58 \\
\text { Patient 3: } 91\end{array}$ & $\begin{array}{l}\text { Patient 1: } 167 \\
\text { Patient 2: } 100 \\
\text { Patient 3: } 162\end{array}$ & 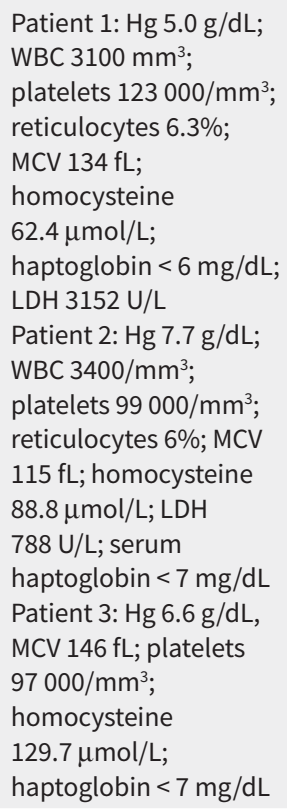 & $\begin{array}{l}\text { Patient 1: } \\
\text { Schistocytes and } \\
\text { hypersegmented } \\
\text { neutrophils } \\
\text { Patient 2: } \\
\text { Macrocytosis with } \\
\text { anisopoikilocytosis, } \\
\text { single } \\
\text { hyperpigmented } \\
\text { neutrophil/ } \\
\text { granulocyte with } \\
\text { schistocyte } \\
\text { Patient 3: NR }\end{array}$ & $\begin{array}{l}\text { Patient 1: } \\
\text { Lethargy, } \\
\text { confusion, } \\
\text { exertional } \\
\text { dyspnea, } \\
\text { difficulty walking, } \\
\text { moderate lower } \\
\text { extremity edema } \\
\text { Patient 2: } \\
\text { Progressively } \\
\text { increasing } \\
\text { fatigue, bilateral } \\
\text { paresthesias, } \\
\text { scleral icterus } \\
\text { Patient 3: } \\
\text { Increasing } \\
\text { fatigue, } \\
\text { exertional } \\
\text { dyspnea, right } \\
\text { upper quadrant } \\
\text { pain }\end{array}$ \\
\hline Andrès et al. ${ }^{5}$ & 201 & $67(\mathrm{SD} \pm 6)$ & $\begin{array}{l}\text { Pseudothrombotic } \\
\text { microangiopathy: } \\
50\end{array}$ & $\begin{array}{l}\text { Mean hemoglobin } \\
10.3 \mathrm{~g} / \mathrm{dL} \text {; } \\
\text { no hematological } \\
\text { abnormalities (56 } \\
\text { [28\%]); } \\
\text { pancytopenia } 12(5 \%) \text {; } \\
\text { pseudothrombotic } \\
\text { microangiopathy } 5 \\
\text { (3\%); } \\
\text { hemolytic anemia } 3 \\
(2.5 \%) ; \\
\text { positive anti-intrinsic } \\
\text { factor antibodies } 3 \\
(2.5 \%)\end{array}$ & $\begin{array}{l}\text { Hypersegmented } \\
\text { neutrophils and } \\
\text { macrocytosis in } \\
\text { two-thirds of } \\
\text { patients }\end{array}$ & $\begin{array}{l}\text { Asymptomatic: } \\
\text { one-third of } \\
\text { patients; } \\
\text { mild sensory } \\
\text { polyneuropathy } \\
\text { or confusion: } 92 \\
\text { patients(46\%); } \\
\text { physical } \\
\text { weakness: } 40 \\
\text { patients (20\%); } \\
\text { bilateral edema } \\
\text { of the legs: } 24 \\
\text { patients (12\%); } \\
\text { jaundice: } 4 \\
\text { patients (2\%) }\end{array}$ \\
\hline Andrès et al. ${ }^{7}$ & 6 & 77 (range 47-89) & 52 (normal 12-74) & $\begin{array}{l}\text { Hemoglobin } 68 \mathrm{~g} / \mathrm{L} \text {; } \\
\text { platelets } 70 \times 10^{9} / \mathrm{L} \text {; } \\
\text { homocysteine } \\
16.2 \mu \mathrm{mol} / \mathrm{L} ; \\
\text { positive anti-intrinsic } \\
\text { factor antibodies } 4 \\
\text { patients }(67 \%)\end{array}$ & $\begin{array}{l}\text { Megaloblastic } \\
\text { anemia and } \\
\text { schistocytes }\end{array}$ & $\begin{array}{l}\text { Asthenia and } \\
\text { dyspnea: } 6 \\
\text { patients (100\%); } \\
\text { jaundice: } 5 \\
\text { patients ( } 83 \%) \text {; } \\
\text { mild peripheral } \\
\text { sensitive } \\
\text { neuropathy: } 3 \\
\text { patients (50\%); } \\
\text { impaired mental } \\
\text { status: } 1 \text { patient } \\
\text { (17\%); peripheral } \\
\text { infiltrated } \\
\text { cutaneous } \\
\text { purpura: } 1 \\
\text { patient (17\%) }\end{array}$ \\
\hline
\end{tabular}


Box 2 (part 2 of 2): Case series and reports of vitamin $B_{12}$ deficiency and hemolysis

\begin{tabular}{|c|c|c|c|c|c|c|}
\hline Study & $\begin{array}{c}\text { No. of } \\
\text { patients }\end{array}$ & $\begin{array}{c}\text { Mean or median } \\
\text { age, } y r\end{array}$ & $\begin{array}{l}\text { Mean cobalamin } \\
\text { level, } \mathrm{pg} / \mathrm{mL}^{*}\end{array}$ & $\begin{array}{c}\text { Other laboratory } \\
\text { values }\end{array}$ & Peripheral smear & $\begin{array}{c}\text { Clinical } \\
\text { presentation }\end{array}$ \\
\hline Chhabra et al. ${ }^{6}$ & 1 & 52 & 116 & $\begin{array}{l}\text { Hemoglobin } 4.2 \mathrm{~g} / \mathrm{dL} \text {; } \\
\text { platelets } 76 \times 10^{9} / \mathrm{L} \text {; } \\
\text { MCV } 136.8 .8 \mathrm{fL} ; \\
\text { reticulocytes } 2.48 \% \text {; } \\
\text { homocysteine } \\
\text { > } 50 \mu \mathrm{mol} / \mathrm{L} \text {; LDH } \\
4050 \mathrm{U} / \mathrm{L} \text {; haptoglobin } \\
<10 \mathrm{mg} / \mathrm{dL} \text {; positive } \\
\text { anti-intrinsic factor } \\
\text { antibodies }\end{array}$ & $\begin{array}{l}\text { Macrocytic } \\
\text { dysmorphic red } \\
\text { blood cells with } \\
\text { slight basophilic } \\
\text { stippling, occasional } \\
\text { schistocytes with } \\
\text { hypersegmented } \\
\text { neutrophils }\end{array}$ & $\begin{array}{l}\text { Fatigue and chest } \\
\text { pain }\end{array}$ \\
\hline Garderet et al. ${ }^{8}$ & 1 & 38 & Undetectable & $\begin{array}{l}\text { Hemoglobin } 4.5 \mathrm{~g} / \mathrm{dL} \text {; } \\
\text { WBC } 2.2 \times 10^{3} / \mathrm{L} ; \mathrm{MCV} \\
90 \mathrm{fL} \text {; platelets } 5 \times 10^{3} / \mathrm{L} \text {; } \\
\text { haptoglobin } 7 \mathrm{mg} / \mathrm{dL} ; \\
\text { total bilirubin } 12 \mathrm{mg} / \mathrm{dL} \text {; } \\
\text { positive anti-intrinsic } \\
\text { factor antibodies }\end{array}$ & $\begin{array}{l}\text { Hypersegmented } \\
\text { neutrophils, } \\
\text { anisocytosis, } \\
\text { schizocytes, and } \\
\text { poikilocytosis }\end{array}$ & Asthenia \\
\hline Noël et al. ${ }^{9}$ & 7 & 72 (range 43-78) & $45 \mu \mathrm{mol} / \mathrm{L}$ & $\begin{array}{l}\text { Hemoglobin } 42 \mathrm{~g} / \mathrm{L} \text {; } \\
\text { platelets } 73 \times 10^{9} / \mathrm{L} \text {; } \\
\text { reticulocytes } 13.1 \times 10^{9} / \mathrm{L} \text {; } \\
\text { MCV } 110.6 \mathrm{fL} \text {; } \mathrm{LDH} \\
7310 \mathrm{IU} / \mathrm{L} \text {; haptoglobin } \\
0.1 \mathrm{~g} / \mathrm{L} \text {; reticulocytes } \\
13.1 \times 10^{9} / \mathrm{L}\end{array}$ & Schistocytes & $\begin{array}{l}\text { Mild confusion: } 2 \\
\text { patients }(28.6 \%)\end{array}$ \\
\hline Kollipara et al. ${ }^{10}$ & 1 & 42 & 59 & $\begin{array}{l}\text { Hemoglobin } 6.8 \mathrm{~g} / \mathrm{dL} \text {; } \\
\text { WBC } 1.3 \times 10^{9} / \mathrm{L} \text {; } \\
\text { platelets } 112 \times 10^{9} / \mathrm{L} \text {; } \\
\text { LDH } 1155 \mathrm{U} / \mathrm{L} \text {; } \\
\text { haptoglobin }<10 \mathrm{mg} / \mathrm{dL} \text {; } \\
\text { positive antiparietal } \\
\text { cell and anti-intrinsic } \\
\text { factor antibodies }\end{array}$ & $\begin{array}{l}\text { Normocytic, } \\
\text { normochromic } \\
\text { anemia with } \\
\text { ovalocytes; } \\
\text { tear-shaped red } \\
\text { blood cells }\end{array}$ & Asymptomatic \\
\hline $\begin{array}{l}\text { Prueksaritanond } \\
\text { et al. }{ }^{11}\end{array}$ & 1 & 52 & $<30$ & $\begin{array}{l}\text { Hemoglobin } 5.9 \mathrm{~g} / \mathrm{dL} \text {; } \\
\text { MCV } 87.1 \mathrm{fL} \text { LDH } \\
701 \mathrm{IU} / \mathrm{L} ; \text { platelets } \\
161 \times 10^{9} / \mathrm{L} ; \text { WBC } 4.7 \times \\
10^{9} / \mathrm{L} ; \text { serum haptoglobin } \\
\text { undetectable; } \\
\text { homocysteine } \\
100 \mu \mathrm{mol} / \mathrm{L} ; \text { reticulocyte } \\
\text { index } 0.4 \%\end{array}$ & $\begin{array}{l}\text { Marked anisocytosis } \\
\text { and poikilocytoisis; } \\
\text { tear drop cells, } \\
\text { elliptocytes and } \\
\text { multiple } \\
\text { schistocytes }\end{array}$ & $\begin{array}{l}\text { Increasing } \\
\text { generalized } \\
\text { fatigue and } \\
\text { weakness; } \\
\text { jaundice }\end{array}$ \\
\hline Yeruva et al. ${ }^{12}$ & 1 & 22 & 60 & $\begin{array}{l}\text { Hemoglobin } 4.8 \mathrm{~g} / \mathrm{dL} \text {; } \\
\text { platelets } 91000 ; \\
\text { haptoglobin } 2 \mathrm{mg} / \mathrm{dL} \text {; } \\
\text { LDH } 1868 \mathrm{IU} / \mathrm{L} ; \\
\text { homocysteine } \\
22.4 \mu \mathrm{mol} / \mathrm{L} \text {; positive } \\
\text { anti-intrinsic factor; } \\
\text { positive antiparietal } \\
\text { cell antibodies }\end{array}$ & $\begin{array}{l}\text { Marked anisocytosis, } \\
\text { hypochromasia with } \\
\text { poikilocytosis, few } \\
\text { schistocytes }\end{array}$ & $\begin{array}{l}\text { Generalized } \\
\text { fatigue and new } \\
\text { onset dyspnea on } \\
\text { exertion; pale } \\
\text { conjunctiva with } \\
\text { icteric sclera }\end{array}$ \\
\hline
\end{tabular}

Note: $\mathrm{LDH}=$ lactate dehydrogenase, $\mathrm{MCV}=$ mean corpuscular volume, $\mathrm{NR}=$ not recorded, $\mathrm{SD}=$ standard deviation, $\mathrm{WBC}=$ white blood cells

*Unless otherwise specified.

We administered 1 unit of packed red blood cells, and her hemoglobin increased to $73 \mathrm{~g} / \mathrm{L}$ with marked improvement in her symptoms. She was subsequently discharged home with vitamin $B_{12}(1000 \mu \mathrm{g}$ subcutaneously daily for six weeks, then monthly), folic acid (5 mg orally daily) and iron sulfate (300 mg orally daily).
At six weeks' follow-up, her symptoms had completely resolved, with normalization of her blood counts (hemoglobin $137 \mathrm{~g} / \mathrm{L}$, platelets $279 \times 10^{9} / \mathrm{L}$ ) and no signs of hemolysis (normal lactate dehydrogenase and total bilirubin). Of note, her serum vitamin $B_{12}$ level normalized, suggesting recovery of her tissue stores. 


\section{In the context of the patient's vitamin $B_{12}$ deficiency, what additional workup should be done?}
a. Bone marrow aspiration
b. Hemoglobin electrophoresis
c. Anti-intrinisc/antiparietal cell antibodies
d. Genetic testing
e. Methylmalonic acid and homocysteine levels

The answer is (c), anti-intrinsic/antiparietal cell antibodies. Homocysteine and methylmalonic acid are metabolic intermediates that accumulate in vitamin $B_{12}$ deficiency, and are typically reserved for cases in which the initial vitamin $\mathrm{B}_{12}$ levels are borderline or inconclusive. Genetic testing should not be performed in this patient, as there is no suspicion for an underlying hereditary hemoglobinopathy. Furthermore, a bone marrow aspirate or biopsy is not appropriate to evaluate vitamin $B_{12}$ deficiency, as the findings typically do not distinguish these deficiencies from other hematologic disorders. Hemoglobin electrophoresis would be appropriate for a suspicion of sickle cell anemia (b) or thalassemia.

In the context of combined vitamin $\mathrm{B}_{12}$ and iron deficiency, we strongly suspected a gastrointestinal malabsorption disorder. Our patient had no anti-intrinsic factor antibodies, but she did have antiparietal cell antibodies, which suggests but is not diagnostic of pernicious anemia. As part of the workup for her severe vitamin $B_{12}$ deficiency, she underwent a gastroscopy with biopsies that were consistent with autoimmune atrophic gastritis.

\section{Discussion}

Clinical manifestations of vitamin $B_{12}$ deficiency are often subtle; however, the consequences of this condition can be serious, with the potential of reversible bone marrow failure and demyelinating disease of the nervous system. Existing case reports and case series have reported substantial heterogeneity in the clinical presentation of patients with hemolysis secondary to vitamin $\mathrm{B}_{12}$ deficiency. ${ }^{3-11}$ In our review of the literature, these patients most commonly presented with fatigue, asthenia, sensory neuropathy or jaundice. A small proportion of patients, however, presented asymptomatically, with evidence of hemolysis noticed incidentally on blood work (Box 2).

In the largest study involving patients with documented vitamin $B_{12}$ deficiency, Andrès and colleagues examined hematologic findings in 201 consecutive patients. ${ }^{4}$ The results showed that less than half of patients presenting with vitamin $B_{12}$ deficiency had the classical hematologic features of macrocytosis and hypersegmented neutrophils on peripheral blood smear. Nearly one-third of patients presented without any hematologic findings. Life-threatening hematologic findings including symptomatic pancytopenia, pseudothrombotic microangiopathy and hemolytic anemia were found in about $10 \%$ of patients. ${ }^{4}$ Other studies in the literature have reported varying hematologic findings including pancytopenia ${ }^{9}$ or autoimmune hemolytic anemia with a positive direct Coomb test result. ${ }^{11}$ Varying blood smear features have been reported, including hypersegmented neutrophils and macrocytosis, schistocytosis, normocytic and normochromic anemia, anisocytosis and poikilocytosis. ${ }^{3-11}$ In our literature review, patients who presented with hemolysis usually had vitamin $B_{12}$ levels of less than $100 \mathrm{pg} / \mathrm{mL}$. A few case reports, however, have described hemolysis in patients with vitamin $B_{12}$ levels between 100 and $200 \mathrm{pg} / \mathrm{mL}$ (Box 2).

The presentation of patients with vitamin $B_{12}$ deficiency can be quite diverse, with varying clinical and hematologic findings that can mimic other illnesses. The peripheral blood smear is an essential first step in investigating the cause of hemolysis, and evidence of megaloblastic changes and schistocytes should direct a physician to suspect vitamin $\mathrm{B}_{12}$ deficiency as the cause of the anemia.

\section{References}

1. Parker V, Tormey CA. The direct antiglobulin test: indications, interpretation, and pitfalls. Arch Pathol Lab Med 2017;141:305-10.

2. George JN, Nester CM. Syndromes of thrombotic microangiopathy. N Engl J Med 2014;371:654-66.

3. Stabler SP. Clinical practice. Vitamin B12 deficiency. N Engl J Med 2013;368:149-60.

4. Acharya U, Gau JT, Horvath W, et al. Hemolysis and hyperhomocysteinemia caused by cobalamin deficiency: three case reports and review of the literature. J Hematol Oncol 2008;1:26.

5. Andrès $E$, Affenberger $S$, Zimmer J, et al. Current hematological findings in cobalamin deficiency. A study of 201 consecutive patients with documented cobalamin deficiency. Clin Lab Haematol 2006;28:50-6.

6. Chhabra N, Lee S, Sakalis EG. Cobalamin deficiency causing severe hemolytic anemia: a pernicious presentation. Am J Med 2015;128:e5-6.

7. Andrès $\mathrm{E}$, Affenberger $\mathrm{S}$, Federici L, et al. Pseudo-thrombotic microangiopathy related to cobalamin deficiency. Am J Med 2006;119:e3.

8. Garderet L, Maury E, Lagrange M, et al. Schizocytosis in pernicious anemia mimicking thrombotic thrombocytopenic purpura. Am J Med 2003;114:423-5.

9. Noël N, Maigné G, Tertian G, et al. Hemolysis and schistocytosis in the emergency department: consider pseudothrombotic microangiopathy related to vitamin B12 deficiency. QJM 2013;106:1017-22.

10. Kollipara VK, Brine PL, Gemmel D, et al. A case of asymptomatic pancytopenia with clinical features of hemolysis as a presentation of pernicious anemia. $J$ Community Hosp Intern Med Perspect 2016;6:32493.

11. Prueksaritanond S, Barbaryan A, Mirrakhimov AE, et al. A puzzle of hemolytic anemia, iron and vitamin B12 deficiencies in a 52-year-old male. Case Rep Hematol 2013;2013:708489.

12. Yeruva SL, Manchandani RP, Oneal P. Pernicious anemia with autoimmune hemolytic anemia: a case report and literature review. Case Rep Hematol 2016;2016:7231503
Competing interests: Dr. Tagalakis reports personal fees from advisory boards (Sanofi, Pfizer, Bayer, Britsol-Myers Squibb and Servier), personal fees from speakers bureaus (Sanofi, Pfizer, Bristol-Myers Squibb), grants or honoraria from a commercial organization (Sanofi), and participation in a clinical trial within the past two years, outside the submitted work. No other competing interests were declared.

This article has been peer reviewed.

The authors have obtained patient consent.
Affiliations: Division of General Internal Medicine (Sapon-Cousineau, Tagalakis), Jewish General Hospital; Faculty of Medicine (SaponCousineau, Elharram, Tagalakis), McGill University, Montréal, Que.

Contributors: Malik Elharram and Vladimir Sapon-Cousineau contributed equally to the production of the manuscript. Vicky Tagalakis contributed to drafting the manuscript and provided editorial review of the manuscript. All of the authors reviewed the final version to be published and agreed to act as guarantors of the work.

Correspondence to: Malik Elharram, malikelharram@gmail.com 